\title{
The Influence of Wind Effects on Architectural Buildings Heights in Iraqi Residential Buildings Based on Computational Fluid Dynamics Simulations
}

\author{
*Ali Hussein Khan, Siti Sarah Herman and Mohamad Fakri Zaky Jaafar
}

First submission: 3 March 2020; Accepted: 22 July 2020; Published: 30 July 2021

To cite this article: Ali Hussein Khan, Siti Sarah Herman and Mohamad Fakri Zaky Jaafar (2021). The influence of wind effects on architectural buildings heights in Iraqi residential buildings based on computational fluid dynamics simulations. Journal of Construction in Developing Countries, 26(1): 63-87. https://doi.org/10.21315/jcdc2021.26.1.4.

To link to this article: $\mathrm{https://doi.org/10.21315/jcdc2021.26.1.4}$

\begin{abstract}
The gradient of height in buildings is the most common way to prepare a comfortable environment and to increase wind forces around the buildings. This study assessed various design choices that enable architectural buildings to have different heights using computational fluid dynamics (CFD) simulation to analyse wind conditions. Nonetheless, wind effects may create uncomfortable zones around high buildings and may be hazardous for pedestrians in open spaces. As such, this study looked into pedestrian level wind (PLW) to enhance the wind environment of buildings in Iraqi climate. Wind characteristics may create a range of disturbance levels that affect pedestrian areas. Iraqi residential buildings were taken as case study to quantitatively analyse the outdoor buildings at PLW, so as to generate some ideas and solutions between CFD simulation analysis and architectural design to yield an optimal model.
\end{abstract}

Keywords: Height buildings, architectural buildings, Computational fluid dynamics (CFD), pedestrian level wind (PLW), Iraqi residential buildings

\section{INTRODUCTION}

Various building heights offer a range of architectural design options in determining the best status of buildings to benefit from the wind environment. A favourable wind environment at the pedestrian level can improve the quality of urban living due to several reasons, including city ventilation (Yuan and Ng, 2012; Du, Mak and Tang, 2018), pollutant dispersion (Cui et al., 2016; Wu, Niu and Liu, 2018), wind comfort (Janssen, Blocken and van Hooff, 2013; Du et al., 2017b), and thermal comfort (Niu et al., 2015; Liu, Niu and Xia, 2016).

Based on Emporis Standards (2015a), high-rise buildings refer to structures with architectural building height ranging between $35 \mathrm{~m}$ and $100 \mathrm{~m}$. With a minimum of 12 floors, a structure is automatically listed as a high-rise, regardless of its height. It is also categorised spontaneously as a high-rise when it has fewer than 40 floors. Another indicator of a high-rise building is when it is more than $23 \mathrm{~m} \mathrm{(75} \mathrm{ft)}$ in height, as stipulated in Section 3.3.25.6 of NFPA's Life Safety Code, 2000 Edition (National Fire Protection Association, 2000). Simply put, various definitions may exist in local authorities that include the number of floors or the height of the building as a criterion. Generally, a high-rise building is a structure with seven stories or more

Department of Architecture, Faculty of Design and Architecture, Universiti Putra Malaysia, Serdang, Selangor, MALAYSIA

*Corresponding author: gs51815@student.upm.edu.my 
(Beadle, 2001). The four categories of high-rise buildings, as prescribed by the national fire incident databases, are 7 to 12 stories, 13 to 24 stories, 25 to 49 stories, and 50 stories or more. The four categories included in high-rise construction are apartments, offices, hospitals, and hotels. The occupancy type is significant in setting the fundamental protection to the buildings, mainly because the resident attributes vary for each building. On the contrary, a low-rise building is defined as an architectural building with a height below $35 \mathrm{~m}$ and divided at systematic intervals into liveable floors (Emporis Standards, 2015b; Gabbar, 2018). This includes all systematic multi-stories buildings that are surrounded, but not fully underground and below the level of a high-rise.

The potential of wind energy in Basra, a southern Iraqi city, was assessed from 2004 to 2008 (Al-Hussieni, 2014). In doing so, statistical data of five-year wind velocity measurements of this city were analysed. The Weibull distribution manner was valued to estimate the wind features behind the meteorological data. The data revealed that the numerical values of the scale parameters for Basra were diversified across vast areas. Alobaydi, Mohamed and Attya (2015) probed into the central region of historic Karbala-Iraq. For both the new and old urban structures, two simulated samples were employed to test airflow velocity and behaviour, whereas the other two samples were utilised to value the local average age of the air. The analysis results of the models were compared to identify the difference in dynamic wind flow circulations before and after the changes in the urban buildings.

A pressing need is present in Iraq to attain a sustainable environment, in which wind effects are sought around Iraqi residential buildings to provide exceptional thermal comfort in urban spaces. Ali et al. (2019) reported that empirical information may serve as a relevant and useful basis to design future urban space.

Another study had focused on several potential mitigation methods to improve the thermal comfort for an urban area at pedestrian level (Ridha, Ginestet and Lorente, 2018). In an arid climate, the human thermal comfort is often affected, especially in urban areas that disregard pedestrians particularly during hot season in summer. Asymmetrical canyons, high-rise buildings, loss of shading feature, lack of vegetation, and huge spacing between buildings are some factors that cause failure in attaining the desired thermal comfort. Numerous studies have proposed methods to improve low wind effects on high-density cities by assessing lift-up design, building porosity, and building height variation. Wind tunnel tests on aerodynamic parameters have been performed to determine the influence of block height variation (Hagishima et al., 2009; Du, Mak and Tang, 2018). Another study that investigated the effect of varied building heights on wind velocity ratio reported that different building heights could improve airfow motion at the pedestrian level wind (PLW) (Ikegaya et al., 2017). Wind velocity ratio is defined as the ratio of wind velocity at the pedestrian level to that at the reference point on the roof (Haberle, 2015). A study revealed that the PLW with an increase in building height improved wind comfort for both isolated buildings and building groups (Du, Mak and Tang, 2018). Blocken and Carmeliet (2004) asserted that increment in wind velocity between two tall buildings stemmed from the interference effect and some modifications made to the Silvertop Tower, in the attempt to enhance pedestrian wind comfort. Wind velocity at pedestrian level can generate high speed on the windward side and near the corners of a building, especially when wind struck a tall building surface and got deflected towards the ground (Mittal et al., 2013). Wind pressure changes in taller buildings due to the combination of downwash and interference effects of wind. Building downwash effect occurs 
when the wind blows against a tall building and the wind is emitted near a building by the airflow over and around the building (Canepa, 2004). In fact, many urban authorities demand studies involving pedestrian wind environment due to the significance of outdoor wind climate for large construction projects.

As such, this study assessed the effect of airflow on different architectural building heights with PLW under hot and dry climate conditions. This study is motivated by the research gap identified on the outdoor wind PLW under hot and dry climatic conditions across Iraqi areas. Concurrently, most prior studies have focused on individual built cases and a single height to evaluate the wind effects on buildings, thus failing to accurately reflect the wind environment laws. Additionally, there is shortage in architectural studies stemming from lack of due consideration of design requirements and actual planning in residential building projects. These are the underlying motivation for the numerical simulation undertaken in this present study by determining the impact of building heights on wind environment in residential buildings based on $\mathrm{k}-\varepsilon$ turbulence model. It is indeed essential to analyse the different and similar building height aspects of Iraqi residential buildings in a comprehensive manner to provide a systematic reference on wind environment and to identify the integral indicators for planning of high-rise buildings.

\section{LITERATURE REVIEW}

\section{Wind Flow}

In built-up areas at big cities, residents' activities, new organisational structures, information technology, environmental concerns, global competition, varied working practices, and flexible employment arrangements have altered the present buildings to suit the residents' requirements (Kincaid, 2003; Prihatmanti and Bahauddin, 2014). Wind flow assessments around high-rise buildings are fundamental for ensuring human health and pollution dispersion at the pedestrian level (Yuan, Ng and Norford, 2014; Zhang et al., 2015; labal and Chan, 2016). Intensive regions are produced by the wall impact blockage from high constructions (Yang et al., 2015), while air quality is a huge concern in urban cities (Yang et al., 2015). Numerous building design institutions recommend analysing outdoor wind flow before designing new buildings $(\mathrm{Ng}, 2009)$. A range of numerical techniques have been used to assess wind flow patterns around high-rise structures within pedestrian level and canopies (Blocken and Stathopoulos, 2013; Blocken, 2015). Based on the airfow patterns in a particular zone through the design stages, building parameters, such as building separation and orientations, have been studied due to advances in modelling methods.

Many researchers performed outdoor investigations to identify suitable wind comfort surrounding buildings, particularly in light of PLW. For instance, Stathopoulos (2013) studied all the current requirements for outdoor environment, particularly air temperature, relative humidity, and wind speed, to ensure thermal comfort around varying structures. Within the wind engineering domain, Computational Fluid Dynamics (CFD) software is marked with advances in computational energy (Blocken, 2014). For wind flow valuation, some researchers concentrated on comfort criteria, such as Yang, Qian and Lau (2013) who described an approach to create a complete convenience index. Most prior studies focused on analysing 
wind flow around buildings with conventional patterns. Past studies have restricted pollution dispersion and wind load in re-entrant bay for irregularly shaped structures (Zhou, Kijewski and Kareem, 2003). Wind flow was studied during a re-entrant bay at a building's midlevel by Chow, Lin and Liu (2002). Meanwhile, Cheng et al. (2011) investigated wind flow through a re-entrant bay and pollution dispersion, whereas other studies conducted an extensive wind tunnel study around building heights at PLW with impacts of building dimensions and platform (Tsang, Kwok and Hitchcock, 2012; Mittal, Sharma and Gairola, 2017). A study explored the impact of twisted wind surroundings on PLW flow for distinct aspect ratio around an isolated building (Tse et al., 2017).

The CFD techniques have been used to study wind flow around buildings with the development of computing power. A CFD simulation was conducted in a study to assess wind speed circumstances in passages between parallel pedestrian and high buildings (Blocken, Carmeliet and Stathopoulos, 2007). Janssen, Blocken and van Hooff (2013) performed CFD PLW simulation for the Eindhoven University of Technology campus and compared various requirements for wind convenience, while Zheng, Li, and Wu (2016) examined PLW environment wind tunnels and CFD simulations on mega-tall building outdoor platforms. A study explored the impact on PLW setting of buildings form, separation, and orientation (labal and Chan, 2016), whereas Du et al. (2017a) looked into the comparable effects on various shapes ( $L$ and $U$ ) of structures using CFD in separate wind directions and concluded that the lift-up design can improve PLW comfort around the lift region.

\section{Wind Velocity}

The significance of safe and comfortable wind velocity has been linked with the vicinity of buildings by a substantial number of authors. Uncomfortable wind velocities noted in new buildings were proven harmful. With the continuous improvement of construction techniques and the accelerated urbanisation process, the outcomes of environmental issues in light of outdoor wind environment have become increasingly integral due to the diversity of high buildings with various layouts across multiple cities (Blocken and Carmeliet, 2004). For instance, high wind velocity would cause discomfort amongst pedestrians or even endanger them due to the narrow channel within the building height. Inappropriate building size or building layout forms a "dead air eddy zone" and contributes to inconvenient airflow between the buildings. Thus, it is vital to determine the formation techniques and development of wind environments.

The tabulated speed of wind reflects the value measured with aerodynamic roughness length $(\mathrm{zO})$ of $0.03 \mathrm{~m}$ over an open terrain at pedestrian height $(1.75 \mathrm{~m})$ (Wieringa, 1992). It is significant to consider that the measurement values are measured within 10 minutes or an hour (steady wind). For instance, Lawson (1975), Murakami, Uehara and Deguchi (1980), Blocken and Carmeliet (2004), and Janssen, Blocken and van Hooff (2013) studied the special sensation ranges of the human body that vary by wind speed (as shown in Table 1). They reported that (1) the range of wind velocity of $0.2 \mathrm{~m} \mathrm{~s}^{-1}$ to $1.1 \mathrm{~m} \mathrm{~s}^{-1}$ is not noticeable wind, (2) wind velocity of $1.1 \mathrm{~m} \mathrm{~s}^{-1}$ to $2.3 \mathrm{~m} \mathrm{~s}^{-1}$ causes wind felt on face, while (3) wind velocity of $2.4 \mathrm{~m} \mathrm{~s}^{-1}$ to $3.8 \mathrm{~m} \mathrm{~s}^{-1}$ will cause newspaper difficult to read, clothing flaps, and hair disturbed. In addition, Bottema (1993) asserted the following: (1) wind velocity of $4 \mathrm{~m} \mathrm{~s}^{-1}$ over a period of $5 \mathrm{sec}$ flaps clothes and disturbs hair, (2) wind velocity of $7 \mathrm{~m} \mathrm{~s}^{-1}$ over a period of $5 \mathrm{sec}$ causes hair to be disarranged, 
(3) wind velocity of $15 \mathrm{~m} \mathrm{~s}^{-1}$ over a period of $2 \mathrm{sec}$ is dangerous for the elderly and may get people out of balance, (4) wind velocity of $20 \mathrm{~m} \mathrm{~s}^{-1}$ is more dangerous and (5) wind velocity of $23 \mathrm{~m} \mathrm{~s}^{-1}$ can eventually blow people over.

Table 1. Land Beaufort's Standard Which Shows Wind Influence on Humans Bodies

\begin{tabular}{|c|c|c|c|}
\hline $\begin{array}{l}\text { Beaufort } \\
\text { Number }\end{array}$ & Description & $\begin{array}{l}\text { Wind Speed at } \\
1.75 \mathrm{~m} \mathrm{Height}^{\left(\mathrm{m} \mathrm{s}^{-1}\right)}\end{array}$ & Effect \\
\hline 0 & Calm & 0.0 to 0.1 & \\
\hline 1 & Light air & 0.2 to 1.0 & No noticeable wind \\
\hline 2 & Light breeze & 1.1 to 2.3 & Wind felt on face \\
\hline 3 & Gentle breeze & 2.4 to 3.8 & $\begin{array}{l}\text { Hair disturbed, clothing flaps, } \\
\text { newspaper difficult to read }\end{array}$ \\
\hline 4 & Moderate breeze & 3.9 to 5.5 & $\begin{array}{l}\text { Raises dust and loose paper, hair } \\
\text { disarranged }\end{array}$ \\
\hline 5 & Fresh breeze & 5.6 to 7.5 & $\begin{array}{l}\text { Force of wind felt on body, dange } \\
\text { of stumbling when entering a } \\
\text { windy zone }\end{array}$ \\
\hline 6 & Strong breeze & 7.6 to 9.7 & $\begin{array}{l}\text { Umbrellas used with difficulty, } \\
\text { hair blown straight, difficult to } \\
\text { walk steadily, sideways wind } \\
\text { force about equal to forwards } \\
\text { walking force, wind noise on ears } \\
\text { unpleasant }\end{array}$ \\
\hline 7 & Near gale & 9.8 to 12.0 & Inconvenience felt when walking. \\
\hline 8 & Gale & 12.1 to 14.5 & $\begin{array}{l}\text { Generally impedes progress, great } \\
\text { difficulty with balance in gusts }\end{array}$ \\
\hline 9 & Strong gale & 14.6 to 17.1 & People blown over \\
\hline
\end{tabular}

Sources: Lawson (1975), Murakami, Uehara and Deguchi (1980), Blocken and Carmeliet (2004) and Janssen, Blocken and van Hooff (2013)

\section{Pedestrian Level Wind (PLW)}

The PLW has a significant effect on the quality of urban occupant's daily life in urban regions. It has an integral role in the dispersal of traffic-related winds, thermal comfort of pedestrians, efficiency of natural ventilation, and pollutants around buildings. The urban regional wind environment may be altered by the existence of buildings. Numerous aspects can affect wind flow patterns around buildings, such as size, morphology, orientation, and configuration of buildings. Occasionally, the alteration of local-wind cases may cause inconvenience to those at PLW. The height of buildings may lead to harsh wind that is dangerous or unsuitable thermal conditions for occupants and pedestrians, while inadequate amount of wind velocity in intense urban regions may cause thermal discomfort in summer. As a result, calm zones and poor wind velocity could be harmful to the wind conditions, wherein urban life quality ought to be examined accurately through urban design stages. 
Apart from wind speed, wind comfort standards and long-term statistical wind data are integral in PLW studies (Shui et al., 2018). Several pedestrian wind comfort criteria have been suggested based on some research work (see Melbourne, 1978; Murakami, Iwasa and Morikawa, 1986; Soligo et al., 1998). The criteria mostly include wind velocity threshold and permissible acceptance of this threshold for pedestrian efficacy. Thus, there are different classifications for various wind environment standards (see Koss, 2006; Sanz-Andres and Cuerva, 2006; Janssen, Blocken and van Hooff, 2013). These comparisons reveal a great variation that exists between various criteria.

Thermal comfort and pedestrian health are vital factors for planning and designing of urban areas. Pollution concentration, temperature, wind velocity, solar radiation, and humidity are some outdoor comfort indicators that are aggravated by the unsuitable design of an urban area (Mirzaei and Haghighat, 2010). Studies have attempted to improve the outdoor environment, particularly at the pedestrian level. The greening of spaces and the planting of trees (Lawson and Penwarden, 1975; Bu et al., 2009), as well as suitable urban design, shading, and material alteration (Blocken, Carmeliet and Stathopoulos, 2007; Yoshie et al., 2007) are some instances that can enhance outdoor air quality. However, it is explicit that the quality of outdoor environment affects indoor environment quality (Murakami, Iwasa and Morikawa, 1986; Wu and Kriksic, 2012). Hence, it is critical to improve outdoor air quality.

\section{Turbulence Modelling}

The fluid flow is a turbulent, laminar, or perhaps a transition between these conditions. Laminar-flow refers to silky streamlines and extremely aligned movement. The intensive flows have highly disordered activity and speed fluctuations. Reynolds number (Re), which determines the flow status, is the ratio of inertia to viscous forces. The laminar stream has low Re because the inertia force is lower than the viscous force. Meanwhile, turbulent flows are distinguished by high Re, as the inertia force is more predominant than the viscous force. Diverse geometries have varying Re values and forces that alter from laminar flow to turbulent flow (Cengel, 2006).

Many turbulence models have been formulated based on CFD simulation, $k-\omega$ model, renormalisation group (RNG) $k-\varepsilon$ model (or standard $k-\varepsilon$ model), largeeddy simulation (LES) and Reynolds averaged Navier-Stokes equation (RANS). It is essential to choose a suitable turbulence model to retrieve dependable outcomes. The most common turbulence in CFD refers to the standard $k-\varepsilon$ model in turbulence models. The eddy viscosity concept is the main pillar of this model. The typical $k-\varepsilon$ model includes a two-equation sample that depends on the turbulence eddy dissipation $(\varepsilon)$ equations and the solution of turbulent kinetic energy $(k)$ (Olsen, 2000; Shaheed, Mohammadian and Gildeh, 2019). The $k-\varepsilon$ model is commonly used in the turbulence models (Awbi, 2002; Blazek, 2015) as it demands lower computer hardware requirement (Awbi, 2002; Chow and Li, 2007). Inaccurate connection between turbulent stresses and turbulent energy production is a problem for two-equation turbulence models, as it is only applicable for high Re flow (Kaiser, Zamora and Viedma, 2009). The typical $k-\varepsilon$ model has developed in terms of the simulation of vortex flow to become RNG $k-\varepsilon$ model (Liu, Lin and Chou, 2009). The RANS turbulence model demands turbulent heat flow and modelling of Reynolds compressions (Blazek, 2015), whereas the fluid flow is divided into small and massive vortexes in the LES turbulence model (Evola and Popov, 2006). 


\section{RESEARCH METHODOLOGY}

This quantitative study looked into the present practice of determining air flow in buildings located at Iraq based on the case study research method using CFD simulation. In order to refute or support different knowledge claims, the information can be subjected and quantified to statistical treatment via quantitative approach (Leedy and Ormrod, 2001; Williams, 2007). The quantitative method is the most widespread method used in studies (Shaffee and Shukor, 2018). Furthermore, (Williams, 2007; Creswel, 2009; Apuke, 2017) by yielding statistical data, experiments, and surveys as data collection methods using predetermined instruments.

Hariri (2012) carried out a quantitative study for the computational experiment of several climatic factors using the ENVI-met model. This study described the traditional public courtyard pattern of the Yazd city (Hariri, 2012). Statistical data of wind velocity measurements of these cities were also utilised in some studies to reveal the potential of wind energy (see Al-Hussieni, 2014; Alobaydi, Mohamed and Attya, 2015). These past studies have extended wind tunnel modelling to CFD simulation as an additional tool (Kim, Kim and Leigh, 2015). In addition, wind tunnel experiment has been performed to study outdoor wind climate. In practical implementation, wind tunnel experiment has some drawbacks. For example, they are difficult and expensive to design with errors composite. Thus, CFD simulation can avert several of the stated problems and may serve as an effective option.

The CFD simulation technologies play a key role to optimise building designs. This study determined cases concerning air flow improvement with CFD simulations to provide some concepts for application of a suitable thermal environment. Overall, these ideas may assist designers and architects to modify and enhance buildings, aside from re-shaping their work styles to be environment-friendly. The CFD strategies were used to study air flow around buildings. For example, Janssen, Blocken, and van Hooff (2013) performed a CFD simulation of PLW for the campus of Eindhoven University of Technology and conducted a comparison of various wind comfort standards. One study examined the impact of building orientation, shape, and separation on PLW effects (labal and Chan, 2016), while another study used wind tunnel and CFD simulation of PLW environment on out space platforms of huge and tall buildings (Zheng, Li and Wu, 2016).

This present study used the Autodesk@2018 CFD simulation software (Autodesk, Inc., California, USA) to define the effect of building heights and orientation on air flow around the buildings.

\section{Study Area}

Najaf city of Iraq, particularly the Al Salam Residential Complex, was selected as the case study due to its prevailing dry and hot climate. Najaf city is about $160 \mathrm{~km}$ in the south of Baghdad city (Akram, Ismail and Franco, 2016) (as shown in Figure 1). 


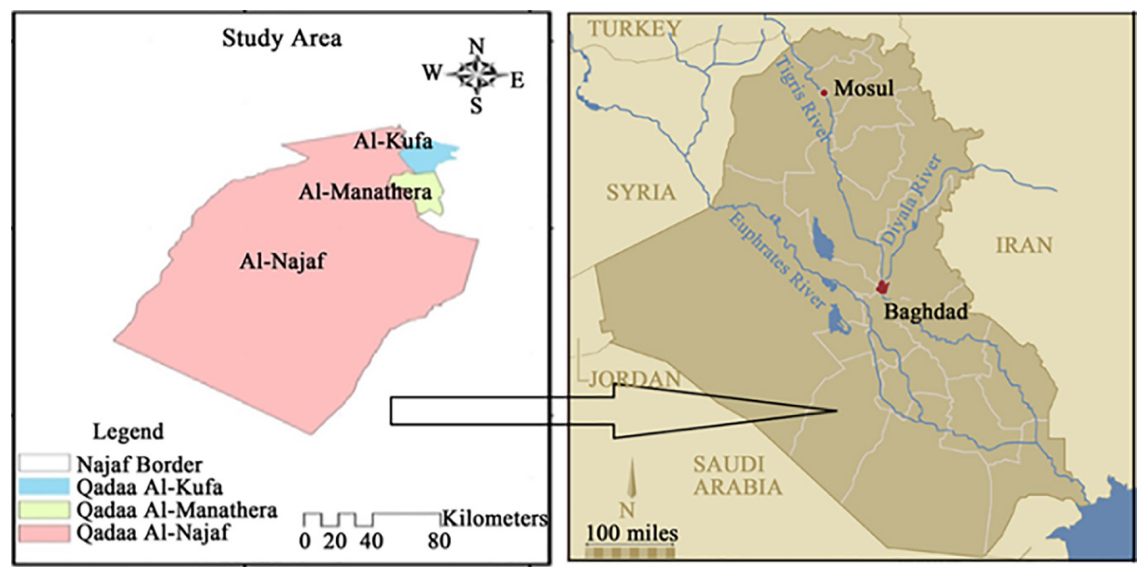

Figure 1. The Regional Boundaries of Najaf City, Iraq Source: Al-Anbari et al. (2016)

The Al Salam Residential Complex is situated in the northern part of the Najaf city. It is bordered from the east by Al-Salam residential neighbourhood and from the west by the northern Najaf garage. Its distance from the Najaf Sea is about $5.75 \mathrm{~km}$ (as shown in Figure 2).

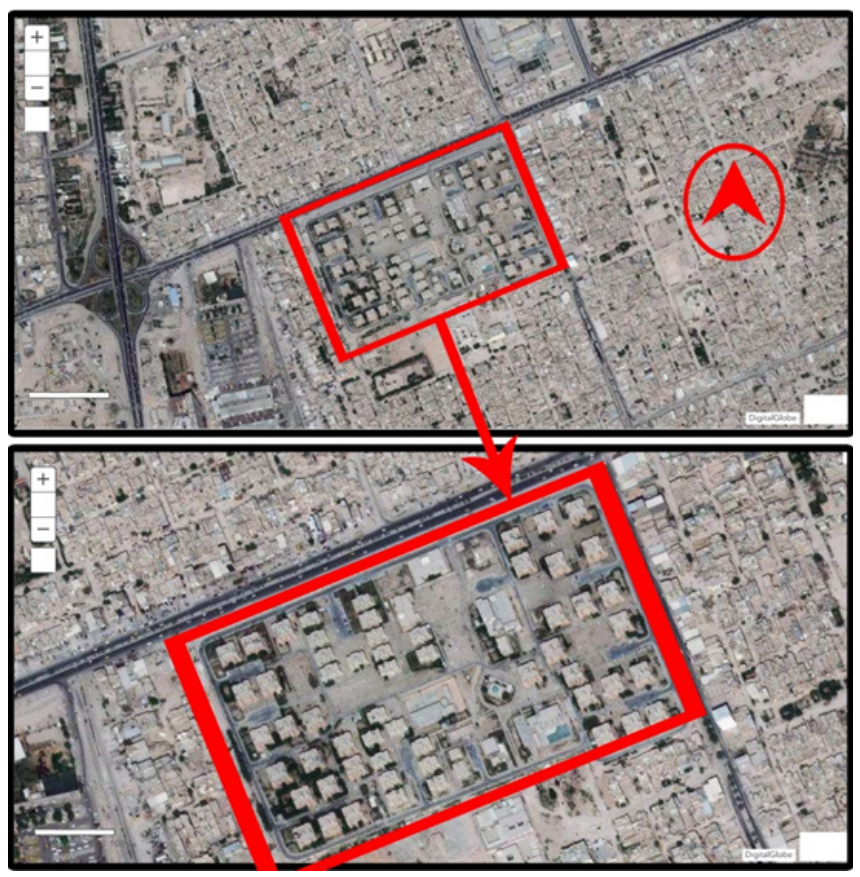

Figure 2. Al-Salaam Residential Building Which is Located in Najaf in Iraq (Retrieved from Zoom Earth, https://zoom.earth/\#view=32.033058,44.331837,18z) 


\section{Data Collection}

Data were obtained from the Meteorological Organisation of Najaf that contained weather records. The data were analysed to determine the design and to yield optimal findings. The data were analysed using computer applications, such as AutoCAD to draw the figures and CFD simulation for data evaluation.

\section{Analysis scope for building heights based on CFD simulation}

Despite the different building heights, the fundamental force that allowed wind pressure ventilation was caused by the pressure difference on the surfaces of the buildings. Wind pressure value on the surfaces of buildings was obtained via CFD simulation to determine the possibility of wind pressure ventilation. The CFD simulation was carried out to optimise and assess the wind flow path, in order to efficiently enhance air flow and ventilation for different building heights, openings, and outdoor spaces. For spaces surrounding different building heights, CFD simulation was conducted to detect wind speed, which could be less secure and convincing for the occupants. Wind environment has an effect on human body sensation to a high degree. When human activities exist in outdoor environment, the physical environment of about $1.75 \mathrm{~m}$ above ground can affect one's sensation most instantly (Guo, Liu and Yuan, 2015).

Based on the Najaf Meteorological Organisation in 2019, the average annual rate of wind speed change during the months of the hot season in that year ranged from $3.2 \mathrm{~m} \mathrm{~s}^{-1}$ to $2.7 \mathrm{~m} \mathrm{~s}^{-1}$ in June, while a reduction was observed during the cold season with wind speed averages of 1.2, 1.4 and $1.9 \mathrm{~m} \mathrm{~s}^{-1}$ in December, January, and February, respectively, wherein the prevalent wind blew from the north-western. Consequently, the wind power and direction in Najaf with only the wind pressure considered. In this study, wind speed at 1.2, 2.2 and $3.2 \mathrm{~m} \mathrm{~s}^{-1}$ were set for the outdoor wind environment at north-western of the residential buildings (as shown in Table 2).

Figure 3 illustrates the analytical study for the wind movement that can affect high buildings. Figure 4 portrays two choices of different and similar building heights to obtain the simulation results of the wind environment where it will be increasing the building height per $5 \mathrm{~m}$ every step. This provides wide ranging values; each of these choices was examined with a ventilation path to start from the north-western direction to the southeast direction of the site based on the prevailing winds in Iraq during summer. Overall, this signified multiple possibilities of the building forms.

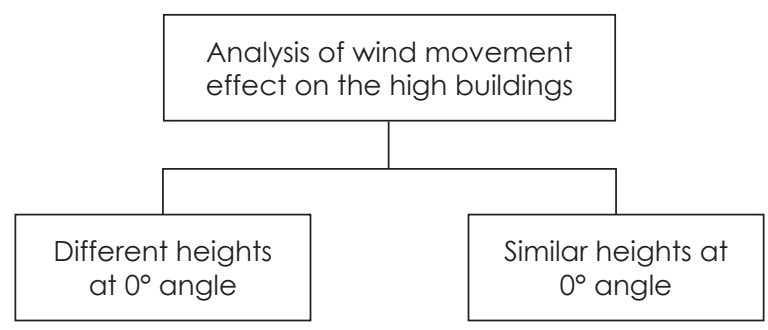

Figure 3. The Analytical Study of the Wind Movement Which Effect on the High Buildings 


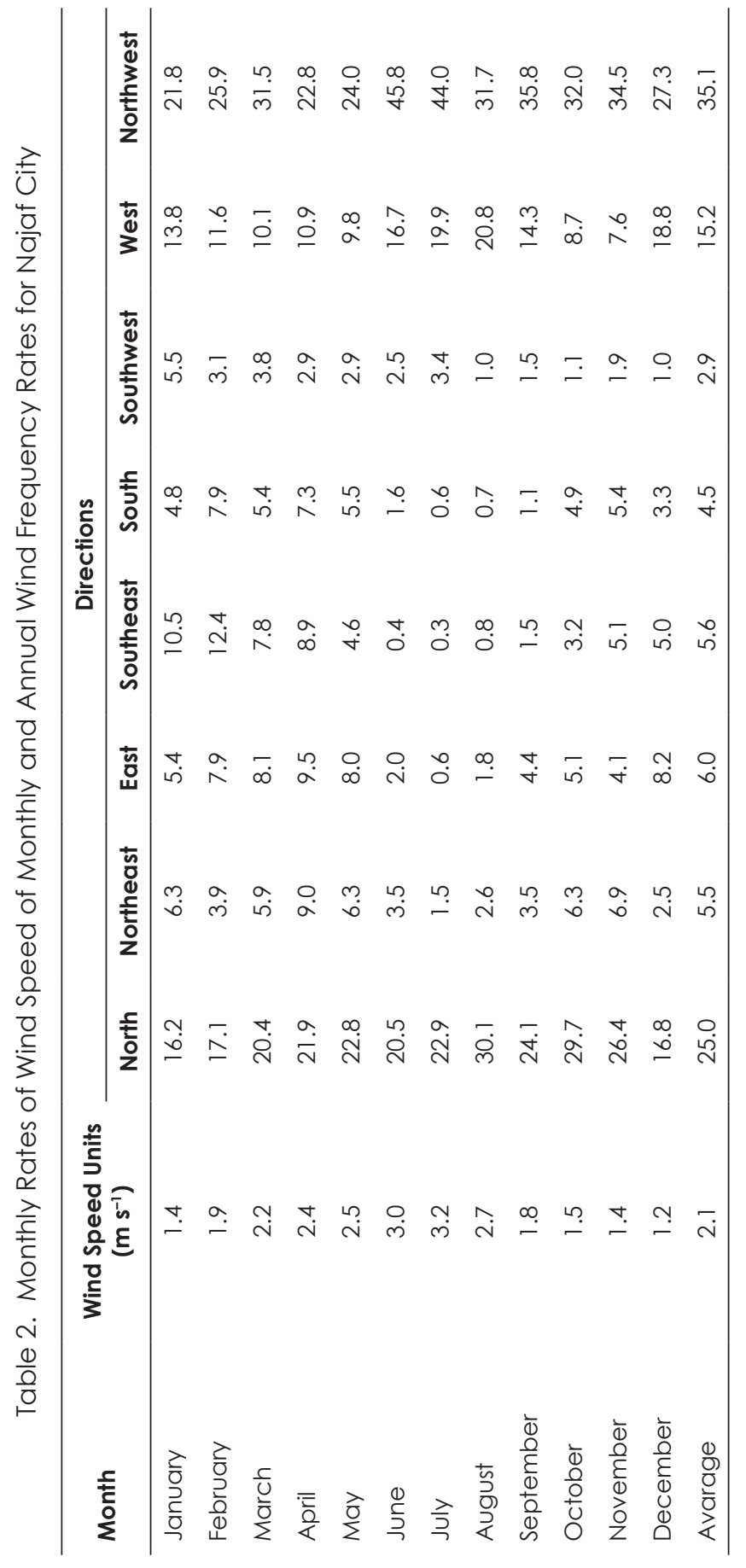



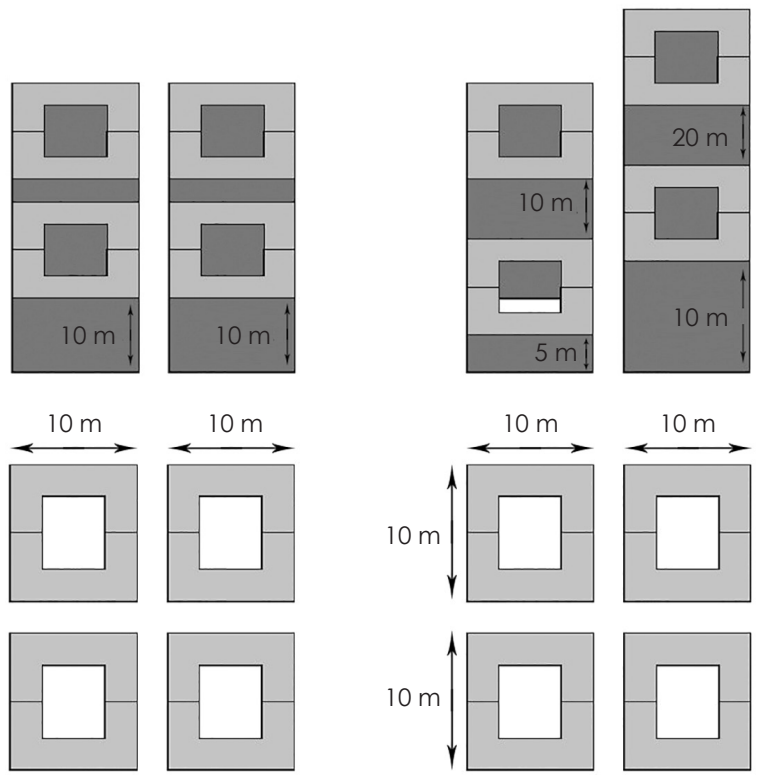

Figure 4. Two Choices of Different and Similar Buildings Heights

\section{Computational Domain}

The model was built using AutoCAD drawings and the design was produced without gaps and details that can be removed. Where their existence led to slow simulation, further conditions were found in the form by reviewing the instructions attached to the programmes. The CFD scenarios contain multiple variables to study amongst them, so as to help in decision making (as shown in Figures 5 and 6).

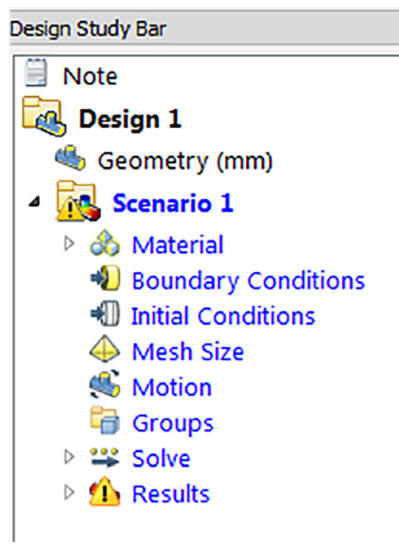

Figure 5. Autodesk CFD Simulation Settings to the Simulation Scenario 


\begin{tabular}{|l|l|l|l||}
\hline $\begin{array}{l}\text { Properties for Air (fixed) } \\
\text { Environment: 101325 Pa, } 19.85 \text { Celsius (from scenario) }\end{array}$ \\
\hline Property & Value & Units & $\begin{array}{l}\text { Underlying } \\
\text { variation }\end{array}$ \\
\hline \hline Density & 1.20473 & $\mathrm{~kg} / \mathrm{m} 3$ & Equation of State \\
\hline Viscosity & $1.817 \mathrm{e}-05$ & Pa-s & Constant \\
\hline Conductivity & 0.02563 & $\mathrm{~W} / \mathrm{m} K$ & Constant \\
\hline Specific heat & 1004 & $\mathrm{~J} / \mathrm{kg} K$ & Constant \\
\hline Cp/Cv & 1.4 & none & Constant \\
\hline Emissivity & 1 & none & Constant \\
\hline Wall roughness & 0 & meter & Constant \\
\hline \hline Phase & 0 & & Vapor Pressure \\
\hline
\end{tabular}

Figure 6. The Physical Properties of Wind in the Simulation Programme

The simulation aspects and the physical properties used employed to determine how the cluster interacted with its surrounding effects based on the surrounding conditions, such as flow rate and pressure.

\section{Boundary Conditions}

Boundary conditions (circumstance) are forces that affect the simulation process. Neutral atmospheric boundary layer profiles for average wind velocity, turbulent kinetic energy, and turbulence dissipation rate should be imposed at the inlet of the domain (Janssen, Blocken and van Hooff, 2013). Both the computational domain and modelling planning are specified in Figure 7. Wind speed was set at $1.2 \mathrm{~m} \mathrm{~s}^{-1}, 2.2 \mathrm{~m} \mathrm{~s}^{-1}$ and $3.2 \mathrm{~m} \mathrm{~s}^{-1}$.

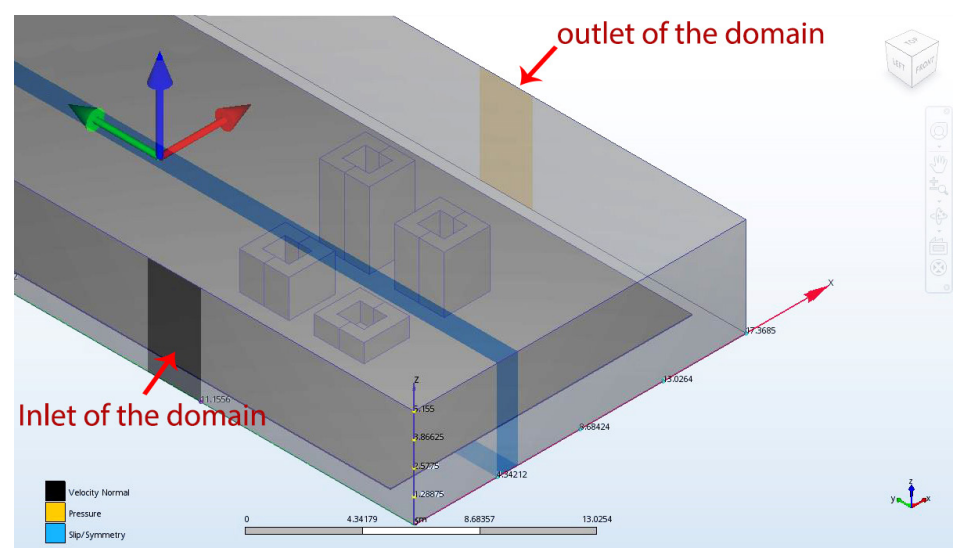

Figure 7. The Inlet and Outlet of the Domain in the Boundary Condition 
Zero static pressure was determined at the outlet of the domain (opposing face of the wind) (as shown in Figure 8). Symmetry boundary conditions were specified at all the remaining sides of the domain (i.e. zero normal velocity and gradients). As for walls, standard walls at all the sides and the top of the domain were applied to simulate the model of the residential building on a total scale.
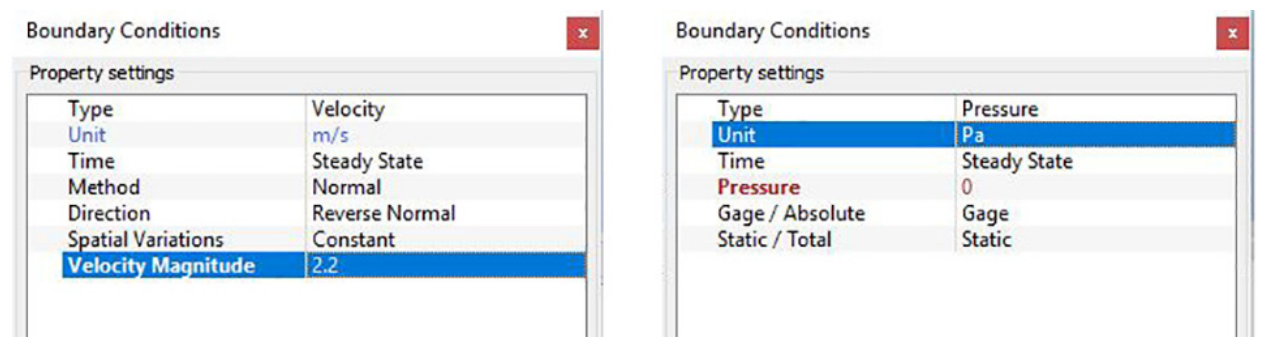

Figure 8. The Boundary Conditions Used in the Simulation Process and their Characteristics

\section{Simulation Mesh Generation}

The model was broken up into small pieces called "elements" prior to the analysis of Autodesk® CFD, while the corner of each element function as a node. Upon calculating out at the nodes, both the nodes and elements generated the mesh (Autodesk, 2015). In the mesh generation process, primary focus was designated to the expansion of high-resolution and high-quality grid, which is usually in triangle form in two-dimensional (2D) simulation, whereas tetrahedron in three-dimensional (3D) simulation (as shown in Figure 9). This study used a computational grid that had 7,450,091 cells of the domain for west and southwest directions of the wind. Different total cell numbers were acquired for other wind directions.
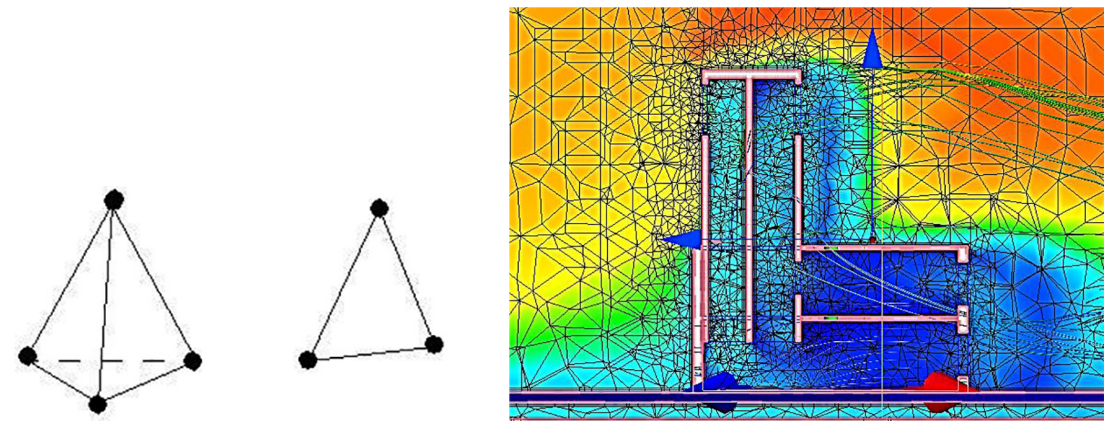

Figure 9. The Process of Meshing for Calculations on Elements and Points 


\section{Other Parameters}

The CFD simulations were carried out using Autodesk® CFD. The $k-\varepsilon$ model was set as the turbulence model; while the number of steps iterations was fixed at 400 steps (as shown in Figure 10).
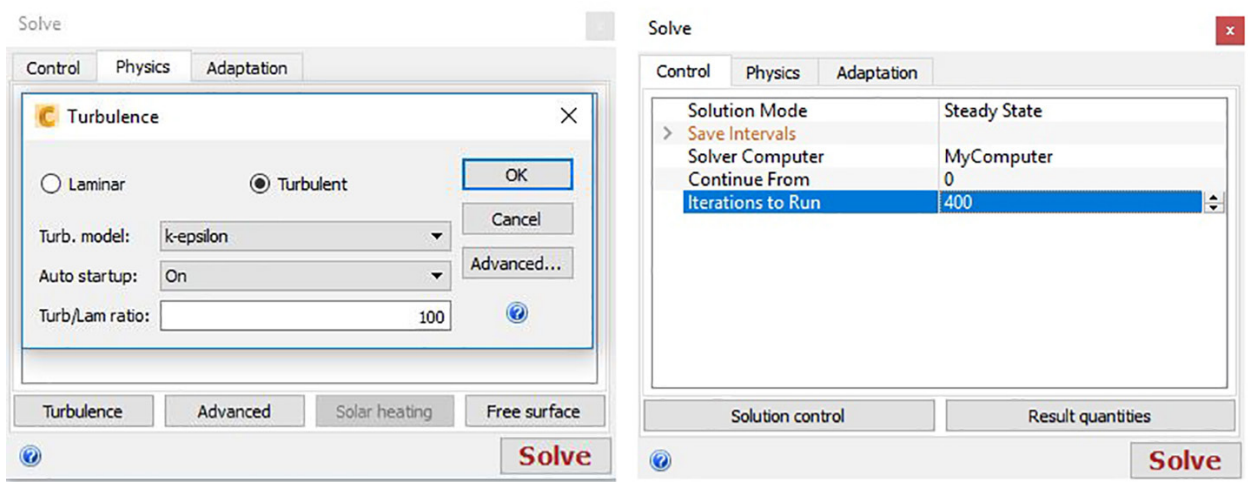

Figure 10. The Iterations Numbers Which Used in the Simulation Process and Turbulence Model

Convergence was acquired when the convergence plot displayed no extra change with increment in the number of iterations. Each CFD simulation was performed with varying iterations. Iterations refer to a numerical sweep over the full model. The convergence of each level of quantity is assigned on the output bar (Convergence Monitor) as illustrated in Figure 11. The results differed from one iteration to another in the initial analysis. The convergence curves and lines fluctuated. The horizontal convergence line points out converged analysis when the outcomes stop changing.

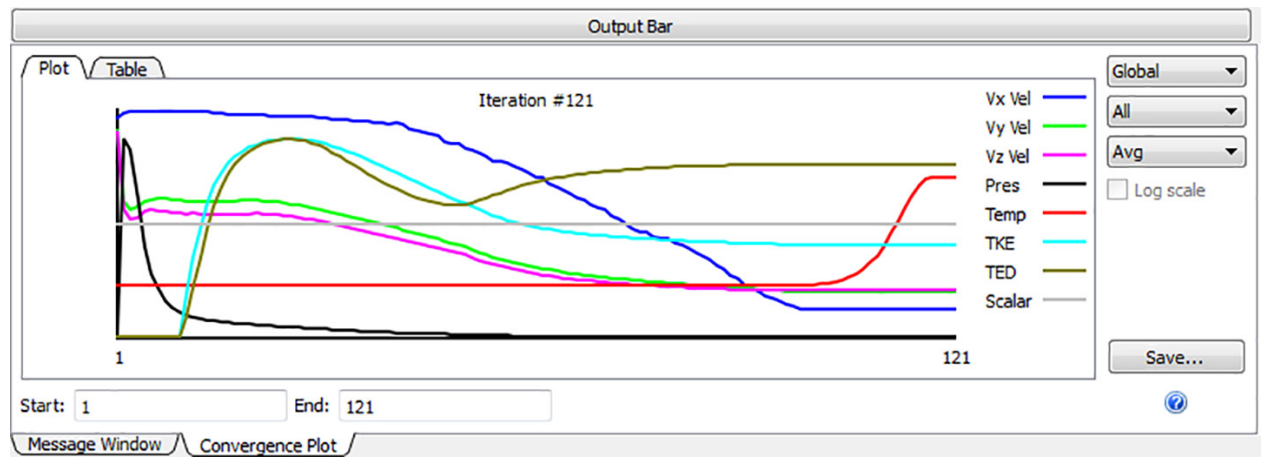

Figure 11. The Convergence Monitor of Autodesk CFD Simulation 


\section{RESULTS OF CFD SIMULATION AND DISCUSSION}

The wind velocity of the study area made one feel comfortable when the wind was within the appropriate range. Table 1 presents the special sensation ranges of the human body that vary by wind speed. In general, outdoor wind velocity that ranges from $1 \mathrm{~m} \mathrm{~s}^{-1}$ to $3.8 \mathrm{~m} \mathrm{~s}^{-1}$ is the most convincing environment for users.

In open space, wind pressure exhibited a more essential role in the wind environment, especially when the inlet air had high wind pressure and the pressure remained steady. Figures 12 to 17 illustrate the wind speed effects on building with two points (points 1 and 2) at $1.75 \mathrm{~m}$ height from the surface of the earth. Figure 12 displays the wind speed in open space that was lower by $0.4 \mathrm{~m} \mathrm{~s}^{-1}$ at point 1 and a maximum of $0.8 \mathrm{~m} \mathrm{~s}^{-1}$ at point 2 when the average of wind speed was $1.2 \mathrm{~m} \mathrm{~s}^{-1}$. Referring to Figure 14, when the average of wind speed was $2.2 \mathrm{~m} \mathrm{~s}^{-1}$, the wind velocity values were $0.4 \mathrm{~m} \mathrm{~s}^{-1}$ and $1.8 \mathrm{~m} \mathrm{~s}^{-1}$ at points 1 and 2, respectively. In Figure 16, wind velocity increased to $3.5 \mathrm{~m} \mathrm{~s}^{-1}$ at point 2 when the average of wind speed was $3.2 \mathrm{~m} \mathrm{~s}^{-1}$.

The wind velocity values of all the models were similar, especially those with the same height. The minimum wind speed observed in point 1 was lower than $1 \mathrm{~m} \mathrm{~s}^{-1}$, thus creating a rather large calm zone as portrayed in Figure 18.

Wind velocity of all the models seemed to change, especially those with different heights. The average wind speed observed in Figure 13 had been $0.8 \mathrm{~m} \mathrm{~s}^{-1}$ and $1.2 \mathrm{~m} \mathrm{~s}^{-1}$ at points 1 and 2, respectively. Several areas at point 2 displayed comfortable zone. Comfortable wind spotted at points 1 and 2 were $1.6 \mathrm{~m} \mathrm{~s}^{-1}$ when the average of wind speed was $2.2 \mathrm{~m} \mathrm{~s}^{-1}$ in (as shown in Figures 15 and 17), and exceeded $2.5 \mathrm{~m} \mathrm{~s}^{-1}$ to $3.2 \mathrm{~m} \mathrm{~s}^{-1}$ when the average of wind speed was $3.2 \mathrm{~m} \mathrm{~s}^{-1}$ in only a few areas (as shown in Figure 19). Therefore, the wind speed was affected by the building height, which could modify the thermal environment in outdoor spaces. However, significant manipulation of building heights minimised large calm zone and changed the wind environment to be moderately comfortable.

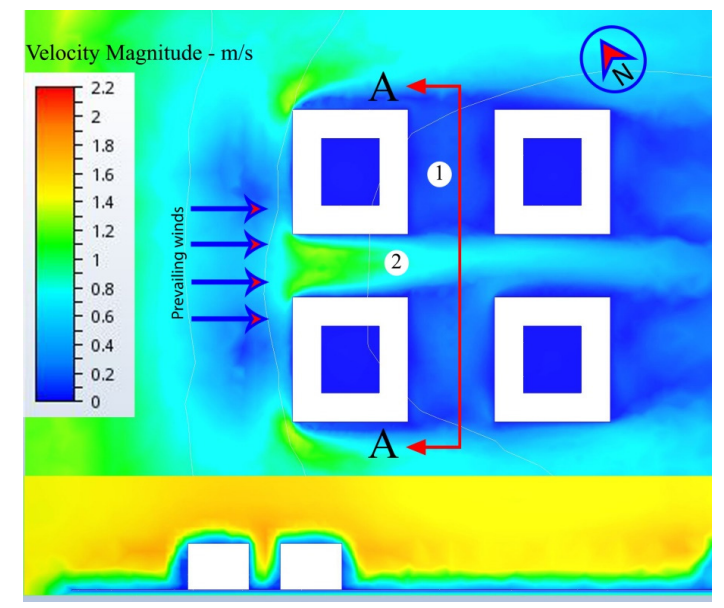

Figure 12. The Similar Buildings Heights When the Average of Wind Speed is $1.2 \mathrm{~m} \mathrm{~s}^{-1}$ and Section A-A 


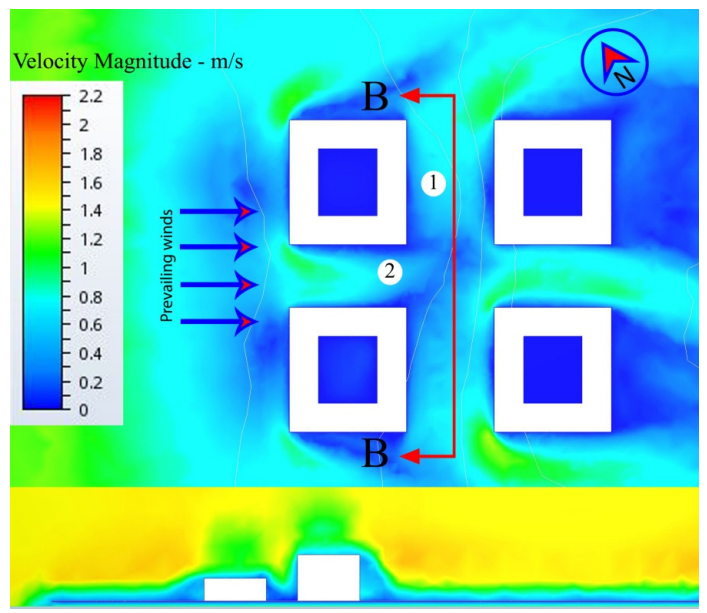

Figure 13. The Different Buildings Heights When the Average of Wind Speed is $1.2 \mathrm{~m} \mathrm{~s}^{-1}$ and Section B-B

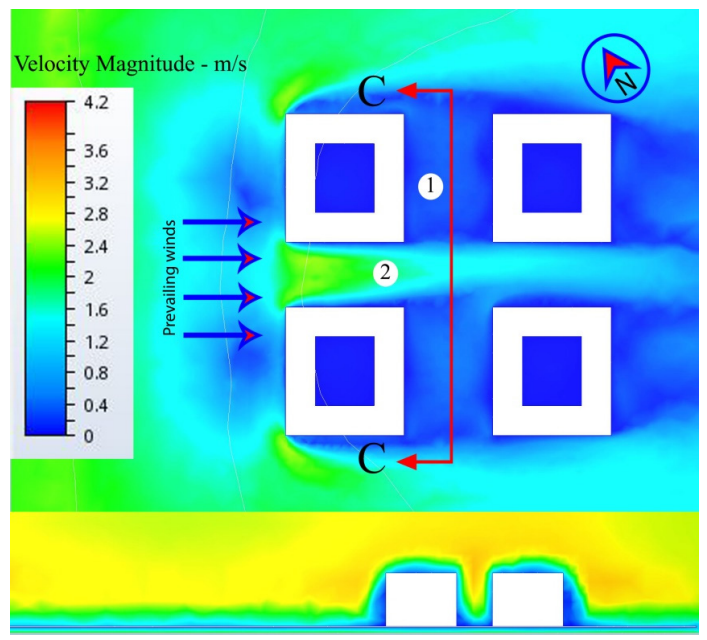

Figure 14. The Similar Buildings Heights When the Average of Wind Speed is $2.2 \mathrm{~m} \mathrm{~s}^{-1}$ and Section C-C 


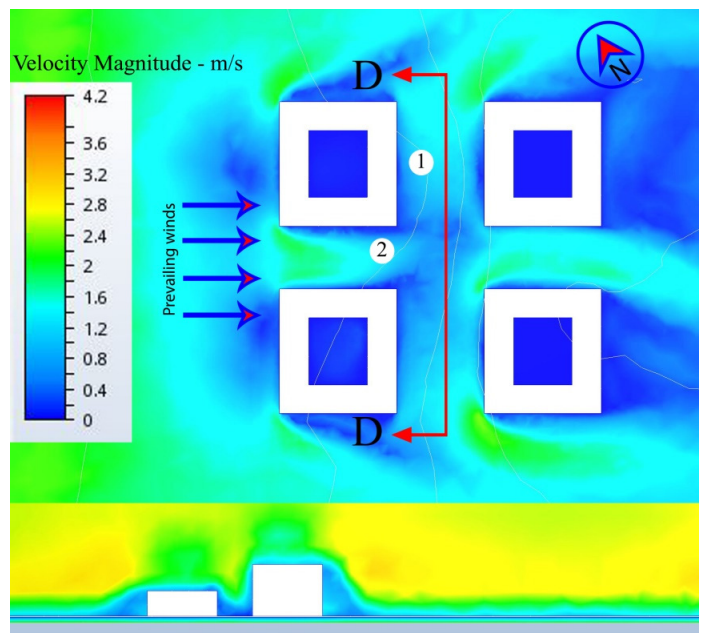

Figure 15. The Different Buildings Heights When the Average of Wind Speed is $2.2 \mathrm{~m} \mathrm{~s}^{-1}$ and Section D-D

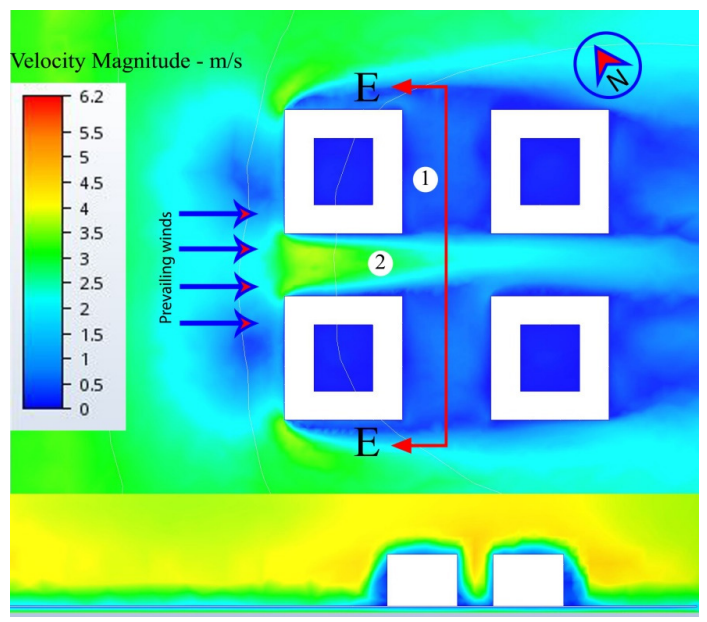

Figure 16. The Similar Buildings Heights When the Average of Wind Speed is $3.2 \mathrm{~m} \mathrm{~s}^{-1}$ and Section E-E 


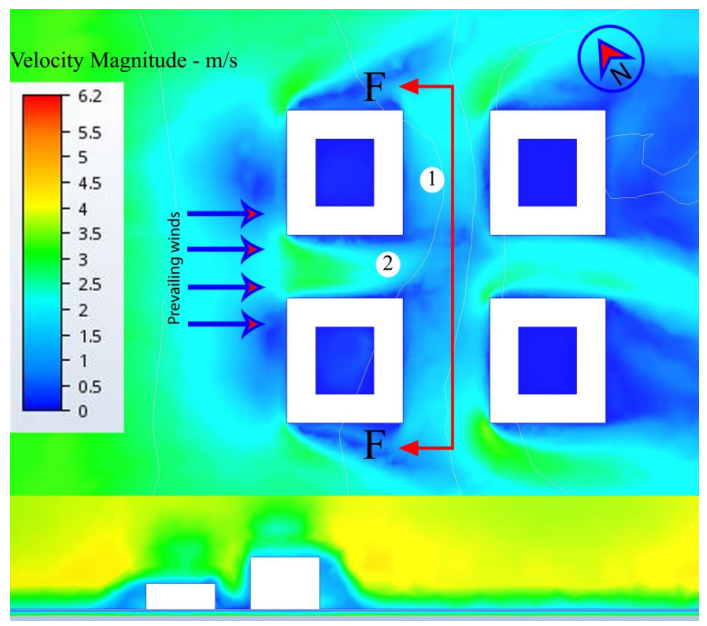

Figure 17. The Different Buildings Heights When the Average of Wind Speed is $3.2 \mathrm{~m} \mathrm{~s}^{-1}$ and Section F-F

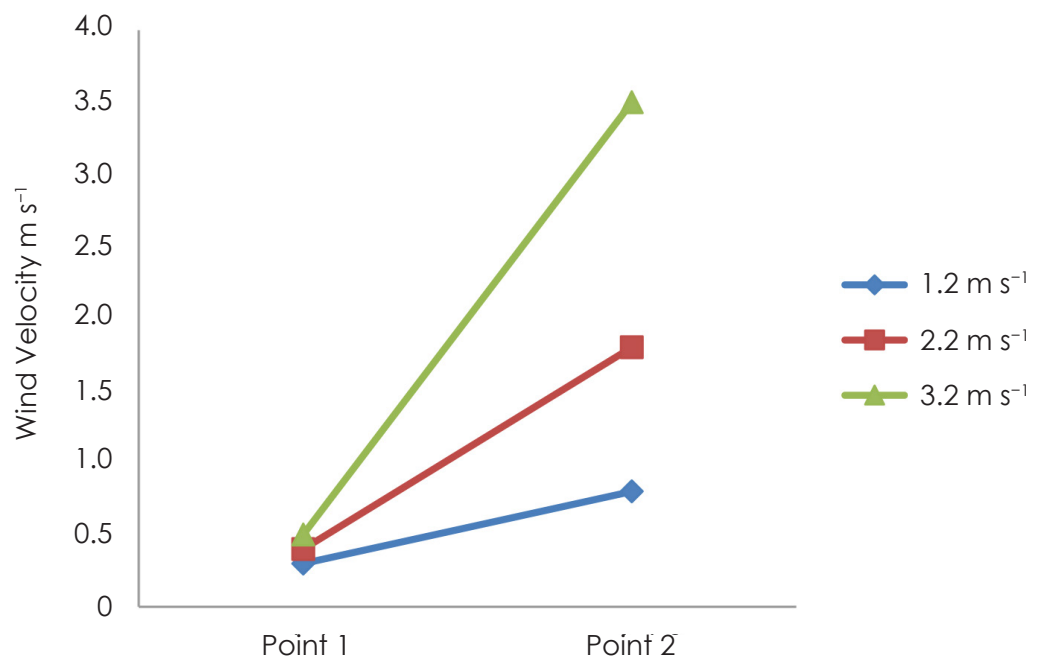

Figure 18. The Similar Buildings Heights When the Average of Wind Speed is $1.2 \mathrm{~m} \mathrm{~s}^{-1}$, $2.2 \mathrm{~m} \mathrm{~s}^{-1}$ and $3.2 \mathrm{~m} \mathrm{~s}^{-1}$ 


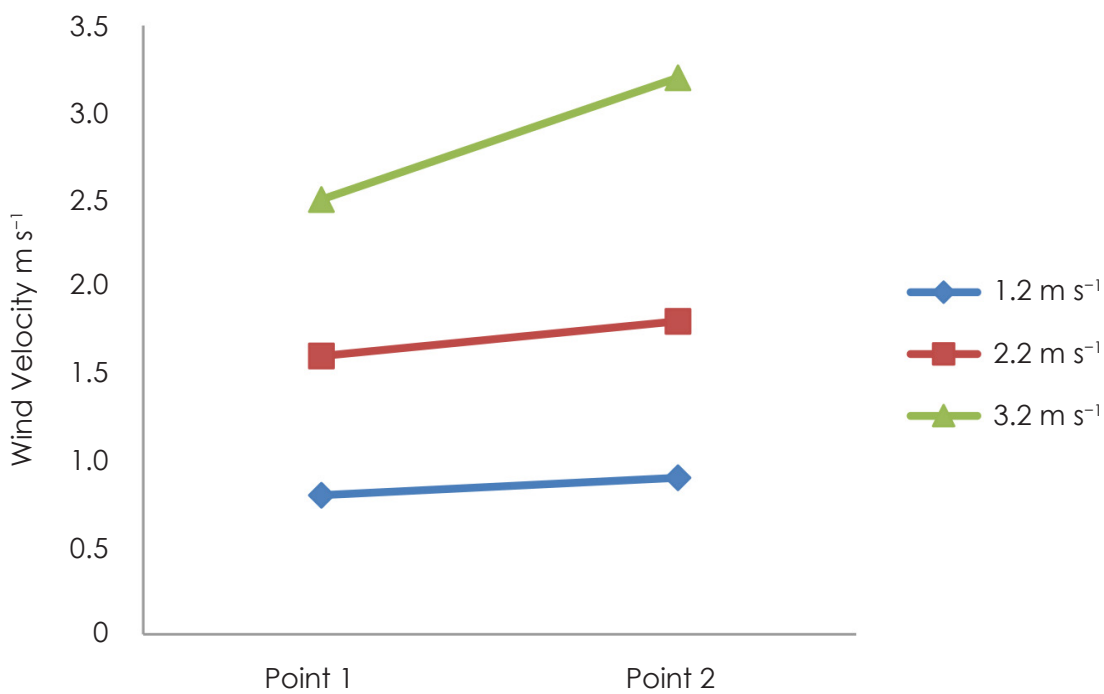

Figure 19. The Different Buildings Heights When the Average of Wind Speed is $1.2 \mathrm{~m} \mathrm{~s}^{-1}, 2.2 \mathrm{~m} \mathrm{~s}^{-1}$ and $3.2 \mathrm{~m} \mathrm{~s}^{-1}$

Past studies (see Rimsha, 1992; Asimakopoulos, 2013) have considered different building heights around the site rather than building them at the same height to gain fine natural ventilation performance in and around the buildings. They added that making some gradient of the building height enabled the shortest one to be exposed to the wind first, while the highest to be exposed to the wind last, in order to avoid the effect of blockage, which is in agreement with Blocken and Carmeliet (2004) and Yuan and Ng (2012). The simulation results of the previous options exhibited that the average wind speed, as described above, was not the best option and the wind speed of all the models had been similar especially those with the same height (as shown in Figures 12, 14, and 16). Nevertheless, the wind speed noted in Figures 13, 15 and 17 reflected the most comfortable average velocity that corresponded with that reported by Mittal et al. (2013). It created the best outdoor wind environment. As asserted by Du, Mak and Tang (2018), wind comfort at the border region can be enhanced with expansion of the target building height. In the windward side of the target building, the results of wind velocity increased remarkably upon increment in building height. When the target buildings shared similar height, the streamline between the target building and the downstream building pointed out a downward flow in these areas. Similarly, Hang et al. (2012) reported that downward flows exist in front of taller buildings, while upward flows exist behind taller buildings. Hence, increasing the height of the target buildings can enhance wind comfort at the pedestrian level, besides changing the wind flow path between the target buildings. Accordingly, the solutions depicted in the case study correspond with past research work, whereby wind speed for all the models had been similar, especially those with the same height. Wind velocity in some areas of the buildings increased as the building generated a convenient zone, thus resulting in a good thermal environment. This is because varied gradients of building heights exerted more impact on buildings with similar height. 


\section{CONCLUSION}

Different building heights are associated with climate design, which can provide users easy direct decisions for their issues with climate, as well as the ability to compensate for their social needs. Manipulating varied building heights has garnered interest among engineers to produce a good design solution for futuristic architecture, equipped with good environmental performance suitable for modern architecture.

This study clearly illustrates that different building heights around the site can generate the best wind flow around the buildings, rather than building them at the same height. The final result indicated that the building design strategy denotes its ability to improve air flow and environmental performance of the external spaces at PLW. However, the building should be in the ratio that is appropriate with the height and the function of the buildings. It is better to have different building heights with gradient at northern facades direction for Najaf city to create the best outdoor wind environment, so as to minimise energy exhaustion and to satisfy the users.

\section{REFERENCES}

Akram, O.K., Ismail, S. and Franco, D.J. (2016). The significant of tourism heritage of najaf city in Iraq. International Journal of Engineering Technology, Management and Applied Sciences, 4(4): 14-19.

Al-Anbari, M., Thameer, M., Al-Ansari, N. and Knutsson, S. (2016). Estimation of domestic solid waste amount and its required landfill volume in Najaf Governorate, Iraq for the period 2015-2035. Engineering, 8(6): 339-346. https://doi.org/10.4236/eng.2016.86031.

Al-Hussieni, A.J.M. (2014). A prognosis of wind energy potential as a power generation source in Basra City, Iraq State. European Scientific Journal, 10(36): 163-176.

Ali, O.H., Ja'afar, N.H., Sulaiman, M.K.A.M. and Khalaf, O.A. (2019). Square as urban space in Iraq: The effectiveness of design attributes on social interaction. International Journal of Recent Technology and Engineering, 7(6): 305-310.

Alobaydi, D., Mohamed, H. and Attya, H. (2015). The impact of urban structure changes on the airflow speed circulation in historic Karbala, Iraq. Procedia Engineering, 118: 670-674. https://doi.org/10.1016/j.proeng.2015.08.501.

Apuke, O.D. (2017). Quantitative research methods a synopsis approach. Kuwait Chapter of the Arabian Journal of Business and Management Review, 6(11): 40-47. https://doi.org/10.12816/0040336.

Asimakopoulos, D. (2013). Passive Cooling of Buildings. London: Routledge. https://doi.org/10.4324/9781315073668.

Autodesk (2015). Flow Design: Wind Tunnel. California: Autodesk. Available at: http://knowledge.autodesk.com/support/flow-design/learn-explore/caas/ CloudHelp/cloudhelp/ENU/FlowDesign/files/GUID-9B85F4A0-5072-454D-8710CCFF26507BE9-htm.html.

Awbi, H.B. (2002). Ventilation of Buildings. London: Routledge. https://doi.org/10 $.4324 / 9780203476307$.

Beadle, L. (2001). Tall Buildings and Urban Habitat. London: CRC Press. https://doi .org/10.4324/NOE0415232418. 
Blazek, J. (2015). Computational Fluid Dynamics: Principles and Applications. Oxford: Butterworth-Heinemann. https://doi.org/10.1016/B978-0-08-099995-1 $.00012-9$.

Blocken, B. (2015). Computational Fluid Dynamics for urban physics: Importance, scales, possibilities, limitations and ten tips and tricks towards accurate and reliable simulations. Building and Environment, 91: 219-245. https://doi .org/10.1016/j.buildenv.2015.02.015.

. (2014). 50 years of computational wind engineering: Past, present and future. Journal of Wind Engineering and Industrial Aerodynamics, 129: 69-102. https://doi.org/10.1016/j.jweia.2014.03.008.

Blocken, B. and Carmeliet, J. (2004). Pedestrian wind environment around buildings: Literature review and practical examples. Journal of Thermal Envelope and Building Science, 28(2): 107-159. https://doi.org/10.1177/1097196304044396.

Blocken, B. and Stathopoulos, T. (2013). Editorial to Virtual Special Issue: CFD simulation of pedestrian-level wind conditions around buildings; Past achievements and prospects. Journal of Wind Engineering and Industrial Aerodynamics, 121: 138-145. https://doi.org/10.1016/j.jweia.2013.08.008.

Blocken, B., Carmeliet, J. and Stathopoulos, T. (2007). CFD evaluation of wind speed conditions in passages between parallel buildings: Effect of wallfunction roughness modifications for the atmospheric boundary layer flow. Journal of Wind Engineering and Industrial Aerodynamics, 95(9-11): 941-962. https://doi.org/10.1016/j.jweia.2007.01.013.

Bottema, M. (1993). Wind climate and urban geometry. PhD diss. Technische Universiteit Eindhoven. https://doi.org/10.6100/IR388789.

Bu, Z., Keto, S., Ishida, Y. and Huang, H. (2009). New criteria for assessing local wind environment at pedestrian level based on exceedance probability analysis. Building and Environment, 44(7): 1501-1508. https://doi.org/10.1016/ j.buildenv.2008.08.002.

Canepa, E. (2004). An overview about the study of downwash effects on dispersion of airborne pollutants. Environmental Modelling and Software, 19(12): 10771087. https://doi.org/10.1016/j.envsoft.2003.11.011.

Cengel, Y.A. (2006). Heat and Mass Transfer. 3rd ed. New York: McGraw-Hill.

Cheng, C.K.C., Lam, K.M., Leung, Y.T.A., Yang, K., Li, D.H.W. and Cheung, S.C.P. (2011). Wind-induced natural ventilation of re-entrant bays in a high-rise building. Journal of Wind Engineering and Industrial Aerodynamics, 99(2-3): 79-90. https://doi.org/10.1016/j.jweia.2010.11.002.

Chow, T.T., Lin, Z. and Liu, J.P. (2002). Effect of condensing unit layout at building re-entrant on split-type air-conditioner performance. Energy and Buildings, 34(3): 237-244. https://doi.org/10.1016/S0378-7788(01)00111-6.

Chow, W.K. and Li, J. (2007). Numerical simulations on thermal plumes with $k-\varepsilon$ types of turbulence models. Building and Environment, 42(8): 2819-2828. https://doi.org/10.1016/j.buildenv.2005.12.006.

Creswel, J.W. (2009). Research Design: Qualitative, Quantitative, and Mixed Methods Approaches. Los Angeles: University of Nebraska-Lincoln.

Cui, D.J., Mak, C.M., Kwok, K.C.S. and Ai, Z.T. (2016). CFD simulation of the effect of an upstream building on the inter-unit dispersion in a multi-story building in two wind directions. Journal of Wind Engineering and Industrial Aerodynamics, 150: 31-41. https://doi.org/10.1016/j.jweia.2016.01.007. 
Du, Y., Mak, C. M., Liu, J., Xia, Q., Niu, J. and Kwok, K.C.S. (2017a). Effects of lift-up design on pedestrian level wind comfort in different building configurations under three wind directions. Building and Environment, 117: 84-99. https://doi.org/10.1016/j.buildenv.2017.03.001.

Du, Y., Mak, C.M. and Tang, B. (2018). Effects of building height and porosity on pedestrian level wind comfort in a high-density urban built environment. Building Simulation, 11(6): 1215-1228. https://doi.org/10.1007/s12273-018 $-0451-y$.

Du, Y., Mak, C.M., Kwok, K., Tse, K.-T., Lee, T., Ai, Z., Liu, J. and Niu, J. (2017b). New criteria for assessing low wind environment at pedestrian level in Hong Kong. Building and Environment, 123: 23-36. https://doi.org/10.1016/j.buildenv.2017.06.036.

Emporis Standards (2015a). Data Standards: Structures; High-Rise Building. München, Germany: Emporis.

- (2015b). Data Standards: Structures; Low-Rise Building. München, Germany: Emporis.

Evola, G. and Popov, V. (2006). Computational analysis of wind driven natural ventilation in buildings. Energy and Buildings, 38(5): 491-501. https://doi.org/ 10.1016/j.enbuild.2005.08.008.

Gabbar, H.A. (2018). Energy Conservation in Residential, Commercial, and Industrial Facilities. Hoboken, NJ: John Wiley \& Sons, Inc. https://doi.org/ 10.1002/9781119422099.

Guo, W., Liu, X. and Yuan, X. (2015). A case study on optimization of building design based on CFD simulation technology of wind environment. Procedia Engineering, 121: 225-231. https://doi.org/10.1016/j.proeng.2015.08.1060.

Haberle, R.M. (2015). Solar system/sun, atmospheres, evolution of atmospheres: Planetary atmospheres; Mars. In G.R. North, J. Pyle and F. Zhang (eds.), Encyclopedia of Atmospheric Sciences. 2nd Ed. Amsterdam: Elsevier, 168177. https://doi.org/10.1016/B978-0-12-382225-3.00312-1.

Hagishima, A., Tanimoto, J., Nagayama, K. and Meno, S. (2009). Aerodynamic parameters of regular arrays of rectangular blocks with various geometries. Boundary-Layer Meteorology, 132(2): 315-337. https://doi.org/10.1007/s10546 -009-9403-5.

Hang, J., Li, Y., Sandberg, M., Buccolieri, R. and Sabatino, S.D. (2012). The influence of building height variability on pollutant dispersion and pedestrian ventilation in idealized high-rise urban areas. Building and Environment, 56: 346-360. https://doi.org/10.1016/j.buildenv.2012.03.023.

Hariri, A.S. (2012). Thermal performance of public courtyards in Yazd, Iran during summer. MSc diss. Universiti Putra Malaysia.

Ikegaya, N., Ikeda, Y., Hagishima, A., Razak, A.A. and Tanimoto, J. (2017). A prediction model for wind speed ratios at pedestrian level with simplified urban canopies. Theoretical and Applied Climatology, 127(3-4): 655-665. https://doi.org/10.1007/s00704-015-1655-z.

labal, Q.M.Z. and Chan, A.L.S. (2016). Pedestrian level wind environment assessment around group of high-rise cross-shaped buildings: Eeffect of building shape, separation and orientation. Building and Environment, 101: 45-63. https://doi.org/10.1016/j.buildenv.2016.02.015.

Janssen, W.D., Blocken, B. and van Hooff, T. (2013). Pedestrian wind comfort around buildings: Comparison of wind comfort criteria based on whole-flow field data for a complex case study. Building and Environment, 59: 547-562. https://doi.org/10.1016/j.buildenv.2012.10.012. 
Kaiser, A.S., Zamora, B. and Viedma, A. (2009). Numerical correlation for natural convective flows in isothermal heated, inclined and convergent channels, for high Rayleigh numbers. Computers and Fluids, 38(1): 1-15. https://doi.org/10.1016/j.compfluid.2007.07.024.

Kim, H., Kim, T. and Leigh, S.-B. (2015). Assessment of pedestrian wind environment of high-rise complex using CFD simulation. Available at: https://www.irbnet .de/daten/iconda/CIB_DC26669.pdf.

Kincaid, D. (2003). Adapting Buildings for Changing Uses: Guidelines for Change of Use Refurbishment. London: Routledge. https://doi.org/10.4324/ 9780203223178.

Koss, H.H. (2006). On differences and similarities of applied wind comfort criteria. Journal of Wind Engineering and Industrial Aerodynamics, 94(11): 781-797. https://doi.org/10.1016/j.jweia.2006.06.005.

Lawson, T.V. (1975). The effect of wind on people in the vicinity of buildings. Paper presented at the 4th International Conference on Wind Effects on Buildings and Structures. Heathrow, London, September.

Lawson, T.V and Penwarden, A.D. (1975). The effects of wind on people in the vicinity of buildings. In K.J. Eaton (ed.), Proceedings of the Fourth International Conference on Wind Effects on Buildings and Structures. Cambridge, UK: Cambridge University Press, 605-622.

Leedy, D. and Ormrod, J.E. (2001). Practical Research Planning and Planning and Design. 7th Ed. Upper Saddle River, NJ: Merrill Practice Hall.

Liu, J., Niu, J. and Xia, Q. (2016). Combining measured thermal parameters and simulated wind velocity to predict outdoor thermal comfort. Building and Environment, 105: 185-197. https://doi.org/10.1016/j.buildenv.2016.05.038.

Liu, P.-C., Lin, H.-T. and Chou, J.-H. (2009). Evaluation of buoyancy-driven ventilation in atrium buildings using computational fluid dynamics and reduced-scale air model. Building and Environment, 44(9): 1970-1979. https://doi.org/10 .1016/j.buildenv.2009.01.013.

Melbourne, W.H. (1978). Criteria for environmental wind conditions. Journal of Wind Engineering and Industrial Aerodynamics, 3(2-3): 241-249. https://doi .org/10.1016/0167-6105(78)90013-2.

Mirzaei, P.A. and Haghighat, F. (2010). A novel approach to enhance outdoor air quality: pedestrian ventilation system. Building and Environment, 45(7): 15821593. https://doi.org/10.1016/j.buildenv.2010.01.001.

Mittal, A.K., Ghosh, D., Behera, S., Siddiqui, I.A. and Dharmshaktu, D.S. (2013). Wind flow simulation in the vicinity of tall buildings through CFD. In N.R. Iyer, P. Krishna, S.S. Rajan and P. Harikrishna (eds.), Proceedings of the Eighth AsiaPacific Conference on Wind Engineering. Singapore: Research Publishing Services. https://doi.org/10.3850/978-981-07-8012-8_329.

Mittal, H., Sharma, A. and Gairola, A. (2017). Pedestrian level wind characteristics around tall buildings: Effect of building shape and wind direction. Paper presented at the 9th Asia-Pacific Conference on Wind Engineering. Auckland, New Zealand, 3-7 December.

Murakami, S., Iwasa, Y. and Morikawa, Y. (1986). Study on acceptable criteria for assessing wind environment at ground level based on residents' diaries. Journal of Wind Engineering and Industrial Aerodynamics, 24(1): 1-18. https://doi.org/10.1016/0167-6105(86)90069-3. 
Murakami, S., Uehara, K. and Deguchi, K. (1980). Wind effects on pedestrians: New criteria based on outdoor observation of over 2000 persons. In J.E. Cermak (ed.), Wind Engineering. Amsterdam: Elsevier, 277-288. https://doi .org/10.1016/B978-1-4832-8367-8.50032-2.

NFPA (National Fire Protection Association) (2000). NFPA's Life Safety Code, 2000 Edition. Quincy, MA: NFPA.

Ng, E. (2009). Policies and technical guidelines for urban planning of highdensity cities-air ventilation assessment (AVA) of Hong Kong. Building and Environment, 44(7): 1478-1488. https://doi.org/10.1016/j.buildenv.2008.06.013.

Niu, J., Liu, J., Lee, T., Lin, Z.J., Mak, C., Tse, K.-T., Tang, B. and Kwok, K.C.S. (2015). A new method to assess spatial variations of outdoor thermal comfort: Onsite monitoring results and implications for precinct planning. Building and Environment, 91: 263-270. https://doi.org/10.1016/j.buildenv.2015.02.017.

Olsen, N.R.B. (2000). CFD Algorithms for Hydraulic Engineering. Trondheim, Norway: The Norwegian University of Science and Technology.

Prihatmanti, R. and Bahauddin, A. (2014). Indoor air quality in adaptively reused heritage buildings at a UNESCO World Heritage Site, Penang, Malaysia. Journal of Construction in Developing Countries, 19(1): 69-91.

Ridha, S., Ginestet, S. and Lorente, S. (2018). Effect of the shadings pattern and greenery strategies on the outdoor thermal comfort. International Journal of Engineering and Technology, 10(2): 108-114. https://doi.org/10.7763/ IJET.2018.V10.1043.

Rimsha, A.H. (1992). Planning and Building Cities in Hot Regions. N.p.

Sanz-Andres, A. and Cuerva, A. (2006). Pedestrian wind comfort: Feasibility study of criteria homogenisation. Journal of Wind Engineering and Industrial Aerodynamics, 94(11): 799-813. https://doi.org/10.1016/j.jweia.2006.06.004.

Shaffee, N. and Shukor, S.F.A. (2018). The effect of natural settings on stress reduction. Alam Cipta, 11 (2): 25-33.

Shaheed, R., Mohammadian, A. and Gildeh, H.K. (2019). A comparison of standard $k-\varepsilon$ and realizable $k-\varepsilon$ turbulence models in curved and confluent channels. Environmental Fluid Mechanics, 19(2): 543-568. https://doi.org/10.1007/ s10652-018-9637-1.

Shui, T., Liu, J., Yuan, Q., Qu, Y., Jin, H., Cao, J., Liu, L. and Chen, X. (2018). Assessment of pedestrian-level wind conditions in severe cold regions of China. Building and Environment, 135: 53-67. https://doi.org/10.1016/j.buildenv.2018.03.006.

Soligo, M.J., Irwin, P.A., Williams, C.J. and Schuyler, G.D. (1998). A comprehensive assessment of pedestrian comfort including thermal effects. Journal of Wind Engineering and Industrial Aerodynamics, 77: 753-766. https://doi .org/10.1016/S0167-6105(98)00189-5.

Tsang, C.W., Kwok, K.C.S. and Hitchcock, P.A. (2012). Wind tunnel study of pedestrian level wind environment around tall buildings: Effects of building dimensions, separation and podium. Building and Environment, 49: 167-181. https://doi.org/10.1016/j.buildenv.2011.08.014.

Tse, K.-T., Weerasuriya, A.U., Zhang, X., Li, S. and Kwok, K.C.S. (2017). Pedestrian-level wind environment around isolated buildings under the influence of twisted wind flows. Journal of Wind Engineering and Industrial Aerodynamics, 162: 12-23. https://doi.org/10.1016/j.jweia.2017.01.002.

Wieringa, J. (1992). Updating the Davenport roughness classification. Journal of Wind Engineering and Industrial Aerodynamics, 41 (1-3): 357-368. https://doi. org/10.1016/0167-6105(92)90434-C. 
Williams, C. (2007). Research methods. Journal of Business and Economics Research, 5(3): 65-72. https://doi.org/10.19030/jber.v5i3.2532.

Wu, H. and Kriksic, F. (2012). Designing for pedestrian comfort in response to local climate. Journal of Wind Engineering and Industrial Aerodynamics, 104: 397407. https://doi.org/10.1016/j.jweia.2012.02.027.

Wu, Y., Niu, J. and Liu, X. (2018). Air infiltration induced inter-unit dispersion and infectious risk assessment in a high-rise residential building. Building Simulation, 11: 193-202. https://doi.org/10.1007/s12273-017-0388-6.

Yang, F., Kang, Y., Gao, Y. and Zhong, K. (2015). Numerical simulations of the effect of outdoor pollutants on indoor air quality of buildings next to a street canyon. Building and Environment, 87: 10-22. https://doi.org/10.1016/j. buildenv.2015.01.008.

Yang, F., Qian, F. and Lau, S.S.Y. (2013). Urban form and density as indicators for summertime outdoor ventilation potential: A case study on high-rise housing in Shanghai. Building and Environment, 70: 122-137. https://doi.org/10.1016/ j.buildenv.2013.08.019.

Yoshie, R., Mochida, A., Tominaga, Y., Kataoka, H., Harimoto, K., NozU, T. and Shirasawa, T. (2007). Cooperative project for CFD prediction of pedestrian wind environment in the Architectural Institute of Japan. Journal of Wind Engineering and Industrial Aerodynamics, 95(9-11): 1551-1578. https://doi .org/10.1016/j.jweia.2007.02.023.

Yuan, C. and Ng, E. (2012). Building porosity for better urban ventilation in highdensity cities: A computational parametric study. Building and Environment, 50: 176-189. https://doi.org/10.1016/j.buildenv.2011.10.023.

Yuan, C., Ng, E. and Norford, L.K. (2014). Improving air quality in high-density cities by understanding the relationship between air pollutant dispersion and urban morphologies. Building and Environment, 71: 245-258. https://doi .org/10.1016/j.buildenv.2013.10.008.

Zhang, Y., Kwok, K.C.S., Liu, X.-P. and Niu, J.-L. (2015). Characteristics of air pollutant dispersion around a high-rise building. Environmental Pollution, 204: 280-288. https://doi.org/10.1016/j.envpol.2015.05.004.

Zheng, C., Li, Y. and WU, Y. (2016). Pedestrian-level wind environment on outdoor platforms of a thousand-meter-scale megatall building: Sub-configuration experiment and wind comfort assessment. Building and Environment, 106: 313-326. https://doi.org/10.1016/j.buildenv.2016.07.004.

Zhou, Y., Kijewski, T. and Kareem, A. (2003). Aerodynamic loads on tall buildings: Interactive database. Journal of Structural Engineering, 129(3): 394-404. https://doi.org/10.1061/(ASCE)0733-9445(2003)129:3(394).

Zoom Earth (n.d.). Map: Al-Salaam residential building. Available at: https://zoom .earth/\#view=32.033058,44.331837,18z. 